\title{
Research on the Protection of Multimedia Works and Intellectual Property Rights
}

\author{
$\mathrm{Nan} \mathrm{He}$ \\ Pingdingshan Industrial College Of Technology, HeNan China
}

\begin{abstract}
Keywords: Protection, Multimedia Works, Intellectual Property Rights
\end{abstract}
\begin{abstract}
The application of multimedia technology brings great convenience to the society at the same time, because the copyright of his works cannot enjoy the corresponding copyright law protection, so that the rights and interests of the creator of the work by the undue harm. I believe that in order to promote the development of multimedia technology, we must continue to reform and improve Chinese intellectual property protection system.
\end{abstract}

\section{Introduction}

In recent years, with the rapid development of multimedia technology, the application of multimedia systems with a strong penetration into people's lives in various fields. Practice tells us that multimedia works have the dual nature of functionality and work. As the copyright law only protects the expression of the works, the concept of ideas contained in the works, principles and other ideas cannot achieve the necessary protective effect. Therefore, this also brings damage to the rights and interests of the creators of multimedia works. In order to maintain the legitimate rights and interests of the writers of multimedia works, the protection of intellectual property rights has become an urgent problem to be studied and solved in today's multimedia production industry.

In the network environment, due to the use of digital technology, the computer will be a certain form (text, value, graphics, images, sound) information into binary digital coding, and then organize, processing, storage, transmission, and when necessary to these digital the information is restored to the original form of information. Thus, people put the binary code in the form of a variety of works expressed as digital works. At present, some scholars have divided the digital works into digital works and digital works. One is to digitize the traditional works such as writing, art, photography, sound, animation, film and television, that is, digital works. In the network environment, digital works and digital works co-exist a need to study the problem, that is, intellectual property protection issues, two forms of work in the protection of intellectual property rights in both the common, there are some differences, to strengthen its research analysis help to improve our network environment in the production, dissemination, the use of digital works of legal awareness, so that intellectual property protection system and work system continues to improve, so that the rights of copyright holders are fully protected, so that the network information industry has been healthy development.

\section{The Concept and Characteristics of Multimedia Works}

Multimedia is in a state of uncertainty, but it is generally believed that multimedia is an environment in which information, such as text, digital, graphic, image, audio, video, and other forms of information are integrated, and the means of use of the media can be used for intelligent operation the work of relying on multimedia technology is the multimedia work.

Multimedia products and databases are similar, is a software, including the complex, it will audio, video, text, images, graphics, animation and other types of information arranged in any arrangement. Multimedia work than the traditional single media form of information density, this situation shows the multimedia works of intellectual property protection of the necessity and importance. Peng Aidong that multimedia works is a variety of information at the same time or alternately expressed works, it is the computer system as the core, the integration of data, text, graphics processing and audio, communications and other technologies, it is implied a higher density of human creation of 
labor the object of protection of intellectual property rights, also known as patent rights, refers to the invention of patent law protection. Chinese "Patent Law" provides that: the term "invention" refers to the invention of utility model and design. Thus, as the object of intellectual property protection in China is the invention and creation, including the invention of utility models and designs.

Multimedia is composed of two parts of media and multi, generally understood as a combination of multiple media. Multimedia is a combination of computer and video technology, in fact it includes more than two media. It is like all modern technology, is composed of hardware and software, or a mixture of machines and ideas. Multimedia can display information, exchange ideas and express emotions, it can enable us to see, hear and understand the ideas of others; can simultaneously collect, process, edit, store and display two or more different types of information media technology. The information media includes text, sound, images, graphics, animations and moving images. So far, multimedia applications have been involved in such industries as advertising, art, education, entertainment, engineering, medicine, business and scientific research.

Multimedia works combine the traditional works of different kinds of belongings, making all kinds of works penetrate each other, greatly improving the work of the copy, processing and modification capabilities. Multimedia works combine information technology with communication technology to obtain information that has been stored in the database in a simple and easy way. Multimedia works are invented and created, and it conforms to the requirements of intellectual property protection. Compared with the traditional media form, multimedia information density is much greater. This also fully demonstrates the need to protect the intellectual property rights of multimedia works and the importance of. Multimedia works have all the characteristics of intellectual property. Multimedia works are a special work. As a work, like other works, it is the expression of human thought and emotion. The particularity of multimedia works is that it relies on computers to express the symbols of human thought and emotion. This symbol is different from that used by other works and cannot be recognized by humans and can only be recognized by computers and their similar machines. This basic attribute of multimedia works also affects the attribution of its copyright. From the relevant provisions of Chinese computer software protection regulations, we can see that, on the one hand, and other works of copyright ownership, the copyright of multimedia works should belong to the developer. On the other hand, if the collaborative development of multimedia works, the copyright of the attribution should be handled in accordance with the copyright works of the contract, the difference is that the written contract is to deal with the basic basis for the copyright of such works. This paper summarizes the characteristics of multimedia works and the intellectual property problems caused by them from four aspects: a. Interactivity and legal status; b. Integration and creative authorization; c. Cooperation and rights attribution; d. Sexual and reasonable use. Multimedia works is not just a simple superposition of the original media form, which itself has many unique features. Such as interact with the user with the Q \& A to complete the exchange of information. Therefore, the protection of multimedia works to the existing copyright law put forward new requirements. Multimedia works with the interaction, software and other characteristics, so that it is different from the existing copyright law to protect the object.

\section{The Copyright and Use of Multimedia Production}

Intellectual property rights involved in the production of multimedia works. In the network environment, the existing works as a material, included, use and the creation of a large number of new situations, especially in the multimedia works to highlight the representative. Most of the multimedia works will be external information as a material to be used or a new creation, while itself will be further become someone else's creative material. The use of external information in the past is based on "citation" and "adaptation", and if there is copyright in the external information of the material, it will lead to the coexistence of power. Multimedia works based on digital technology will be text, images, sound, images and other organic integration into a work, the copyright status is very complex, multimedia works in a variety of media types of works or pieces of work may be copyright has copyright and some have been lost. This requirement is fully considered in the design of the digital 
library information organization structure, and it is possible to reflect the different rights and permissions that make up each element of each information item. Understanding of copyright law, patent law, trademark law and business intelligence law and multimedia development related to intellectual property law can try to avoid multimedia development in the property rights disputes.

Legal basis for the protection of multimedia works. How to coordinate the contradiction between electronic copyright protection and fair use is the topic that legal circles and copyright law scholars are discussing. The establishment of a global information superhighway to the existing copyright law put forward a fundamental problem, the current copyright system cannot protect the interests of the information age copyright holders, it was advocated set of multimedia works, the United States Dr. Andrud Christie that the current copyright system should be simplified, The purpose of creating a new copyright law is to be able to cover the new works of the digital age, the future management by the government will be the only good policy. Two systems can be used to realize the direct management of the government. One is to establish the bidding system and the value evaluation system for the production of the works. The creators of the works can create the works according to the contract arrangement and obtain the private interests. After the works are delivered to the government will lose the right to work, the purpose of the system is to encourage the creation of works. The second is the establishment of information access fee system, all access network information highway users have access rights, and have the obligation to pay the cost. Switzerland has introduced legal licenses in copyright legislation, involving schools, libraries, copy shops and other departments, the copy of the tax rate by the Swiss photocopying rights organizations and user associations in consultation. In other Western countries also have a copy of royalties, recording royalties and other similar provisions, the purpose is to limit the rational use of electronic reproduction to maintain the exclusive right, and copy royalties are mainly schools, libraries, and even some of the original reasonable use, such as for teaching and academic research purposes and copy the works of others and other acts.

Establish a collective management system for multimedia works. I believe that the establishment of multimedia production collective management system is to solve the multimedia production, use of intellectual property protection in the best way, and this initiative has been adopted by many countries or industries, and achieved some results.

\section{The Intellectual Property Protection of Multimedia Works}

Infringement of intellectual property rights in multimedia works refers to acts that violate the relevant legal provisions and damage the exclusive rights of intellectual property owners. The infringement of the intellectual property rights of multimedia works should have the same legal and legal consequences as the general infringement. However, due to the different objects, the infringement of intellectual property rights of multimedia works has its own unique characteristics, such as the particularity of infringement, the highly technical nature of the infringement, the breadth of the scope of infringement, the diversity of the type of infringement. Multimedia works of these unique features, will give its intellectual property protection caused some difficulty. The elements that violate the intellectual property rights of multimedia works should be treated separately from different situations. The burden of liability for damages should adhere to the principle of fault liability, to fault as a key element. The reason why this is mainly due to the intellectual property of multimedia works has the characteristics of intangible, so that the right of the right to exclusive rights of others by the intention of any person or the possibility of negligence and the actual opportunity than other real rights more likely. In other words, there is no fault and the intellectual property rights of other people's multimedia works are damaged, in some cases, with greater universality. Facts have proved that in the intellectual property infringement disputes in multimedia works, the plaintiff proved that the defendant has a fault is difficult, and the defendant to prove that they are no fault is easy. As the maintenance of intellectual property rights of multimedia works has a certain complexity, which also attracted the attention of this industry. The protection of multimedia works as a work by copyright law has become the practice of the vast majority of countries in the world. Chinese 1990 
"Copyright Law" will be computer software included in the copyright law protected works, but in view of the particularity of computer software, the law attached to the provisions of the computer software protection measures, by the State Council separately. May 24, 1991, the 83rd session of the Standing Committee of the State Council adopted the "Computer Software Protection Regulations", the implementation of the same year on October 1 . This is the first law on the computer promulgated by our country. In order to join the WTO and adapt to the needs of information network technology development, December 20, 2001, the State Council re-enacted the "computer software protection regulations", and in January 1, 2002 came into effect. On January 12, 2011, the Supreme People's Court of China, the Supreme People's Procuratorate, the Ministry of Public Security and the Ministry of Justice jointly issued the Opinions on Several Issues Concerning the Application of Law in the Criminal Cases Involving Intellectual Property Infringement. "Opinions" release greatly enhanced our protection of multimedia intellectual property rights.

\section{Conclusion:}

In summary, although the intellectual property protection of multimedia works has a certain legal basis, but because of the particularity of their works, it is difficult to operate, which requires professionals engaged in this industry to vigorously improve their own legal awareness, and constantly enhance the ability to protect their rights and interests according to law. At the same time, we must also enhance the whole society to respect the knowledge, respect for the fruits of other people's consciousness.

\section{References}

[1] B. N. Ma, Multimedia electronic publications and their editorial and creative research. J. Journal of Information.44 (2010) 146-147.

[2] H.X.Zeng, On the Application of Trust System in Collective Management System. J. Copyright. 18(2005) 55-57.

[3] J. H. Xue, Establishing an intellectual property system for the twenty - first century. J. Chinese Soft Science 32(2012) 189-190.

[4] Y.J.Qi, New technology and the development trend of international copyright protection. J. Intellectual Property. 4(2007) 38-40.

[5] Y.M.Tian, Multimedia Technology and Intellectual Property Protection, J. Journal of Jiaozuo University. 4(2011) 128-133. 